Article

\title{
Pressure-Induced Geopolymerization in Alkali-Activated Fly Ash
}

\author{
Sol Moi Park ${ }^{1,+} \mathbb{C}^{\circ}$, Hammad Raza Khalid ${ }^{1,2,+} \mathbb{\infty}$, Joon Ho Seo ${ }^{1}$, Hyun No Yoon ${ }^{1}$, \\ Hyeong Min Son ${ }^{1}$, Seon Hyeok Kim ${ }^{1}$, Nam Kon Lee ${ }^{3}$, Haeng Ki Lee ${ }^{1}$ and Jeong Gook Jang ${ }^{4, *}$ \\ 1 Department of Civil and Environmental Engineering, Korea Advanced Institute of Science and Technology, \\ 291 Daehak-ro, Yuseong-gu, Daejeon 34141, Korea; \\ solmoi.park@kaist.ac.kr (S.M.P.); hrkhalid@kaist.ac.kr (H.R.K.); junhoo11@kaist.ac.kr (J.H.S.); \\ yhn0307@kaist.ac.kr (H.N.Y.); nemilhm@kaist.ac.kr (H.M.S.); \\ kimsh1187@kaist.ac.kr (S.H.K.); haengki@kaist.ac.kr (H.K.L.) \\ 2 Civil \& Environmental Engineering Department, King Fahd University of Petroleum \& Minerals, \\ Dhahran 31261, Saudi Arabia \\ 3 Department of Infrastructure Safety Research, Korea Institute of Civil Engineering and Building Technology, \\ 283 Goyangdae-ro, Ilsanseo-gu, Goyang-si 10223, Korea; nklee@kict.re.kr \\ 4 Division of Architecture and Urban Design, Incheon National University, 119 Academy-ro, Yeonsu-gu, \\ Incheon 22012, Korea \\ * Correspondence: jangjg@inu.ac.kr; Tel.: +82-(0)32-835-8472 \\ + These authors contributed equally to this work.
}

Received: 24 August 2018; Accepted: 25 September 2018; Published: 1 October 2018

check for updates

\begin{abstract}
The present study investigated geopolymerization in alkali-activated fly ash under elevated pressure conditions. The fly ash was activated using either sodium hydroxide or a combination of sodium silicate solution and sodium hydroxide, and was cured at $120^{\circ} \mathrm{C}$ at a pressure of $0.22 \mathrm{MPa}$ for the first $24 \mathrm{~h}$. The pressure-induced evolution of the binder gel in the alkali-activated fly ash was investigated by employing synchrotron $\mathrm{X}$-ray diffraction and solid-state ${ }^{29} \mathrm{Si}$ and ${ }^{27} \mathrm{Al}$ MAS NMR spectroscopy. The results showed that the reactivity of the raw fly ash and the growth of the zeolite crystals were significantly enhanced in the samples activated with sodium hydroxide. In contrast, the effects of the elevated pressure conditions were found to be less apparent in the samples activated with the sodium silicate solution. These results may have important implications for the binder design of geopolymers, since the crystallization of geopolymers relates highly to its long-term properties and functionality.
\end{abstract}

Keywords: geopolymer; fly ash; synchrotron XRD; solid-state MAS NMR spectroscopy

\section{Introduction}

Geopolymers are a cementitious material belonging to a group of alkali-activated binders, which can be synthesized by alkaline activation of aluminosilicate-rich precursors [1,2]. Coupled with the global $\mathrm{CO}_{2}$ emissions associated with the production of Portland cement, this binder system is viewed as a potential sustainable cement [3-5]. Geopolymers are known to exhibit excellent durability performance [6,7], providing a potential application to various fields in place of ordinary Portland cement [8].

Fully-reacted geopolymeric gels are totally amorphous [9]. However, they may present a nanostructural analogue to zeolite, possibly due to the similarities between the chemical compositions of both materials $[10,11]$. The nanostructure of geopolymers consists of alkali-aluminosilicate gel, often abbreviated as N-A-S-H (where N denotes sodium, which is the most commonly employed alkali), where both $\mathrm{Si}$ and $\mathrm{Al}$ are in tetrahedral coordination [2]. A recent study conducted by Brant et al. [12] revealed that $\mathrm{Q}^{4}(4 \mathrm{Al}), \mathrm{Q}^{4}(3 \mathrm{Al}), \mathrm{Q}^{4}(2 \mathrm{Al})$, and $\mathrm{Q}^{4}(1 \mathrm{Al}) \mathrm{Si}$ units are predominantly present in sodium 
aluminosilicate gels, which are charge-balanced by three to four coordinated $\mathrm{Na}^{+}$ions and $\mathrm{H}_{2} \mathrm{O}$ molecules, or six coordinated $\mathrm{Al}$ atoms. This study also identified that the presence of $\mathrm{Al}^{3+}$ in sites with lower symmetry provided charge-balancing capacity [12].

The durability and other physicochemical properties of geopolymers are attributed to the nanostructure of the aluminosilicate gel. Binders derived from alkali-activated fly ash present excellent resistance against a number of chemical degradation phenomena, which are known to be devastating in the case of Portland cement [13-15]. The aluminosilicate gel formed in geopolymers possesses negatively-charged surfaces and a high specific surface area, which are ideal for the adsorption of cationic pollutants such as heavy metals $\left(\mathrm{Pb}^{2+}\right)[16,17]$ and radionuclides $\left(\mathrm{Cs}^{+}, \mathrm{Sr}^{2+}\right)[8,18,19]$.

The nucleation of zeolites with the ageing of geopolymers can lead to reduced mechanical strength and durability, as observed by Silva and Crenstil [20]. Thus, it is crucial to assess the factors that lead to the transformation of amorphous geopolymeric gel into crystalline zeolites to ensure the long term properties of geopolymers. The effect of elevated pressure during the manufacture of geopolymers and enhanced zeolite yield has been extensively investigated in previous studies. The strength of fly ash-based geopolymers varies according to the curing conditions and precursor/activator composition. While the strength of those cured at an elevated temperature and ambient pressure can be as high as $40 \mathrm{MPa}$ at 28 days [21,22], and have the potential to develop further at later ages [23], the geopolymer specimens, in which a significant amount of aluminosilicate gel is transformed into crystalline zeolite at an elevated pressure, show limited strength (i.e., as low as $2 \mathrm{MPa}$ at 28 days [24]). While the strength decline in geopolymers via crystallization is a generally acknowledged deterioration phenomenon of geopolymers, its nanostructural characterization remains limited.

Zeolite formation in alkali-activated materials can be affected by a number of factors, i.e., the Ca content in the precursors can lead to precipitation of Ca-chabazite [24]. Faujasite and sodalite are the two zeolite crystals commonly observed in fly ash-based binders, in which inert minerals such as quartz and mullite can be consumed as reactants for zeolite formation in the presence of elevated pressure [16]. Hydrothermal treatment is a conventional method for artificially synthesizing zeolites from silica and alumina source materials [25]. Under suitable pressure and humidity conditions, pure phase zeolites can be synthesized with high yield. Curing geopolymers under elevated pressure conditions at an early age can be a robust way to study the factors controlling this transformation, and to predict their long-term properties. Hence, geopolymers were cured under elevated pressure conditions in this study to explore the effects of different activating solutions.

\section{Experimental Procedure}

\subsection{Materials}

The chemical composition of the fly ash (supplied by Hadong thermal power plant in South Korea) used in this study is shown in Table 1. The alkali-activated fly ash paste samples were synthesized using $9 \mathrm{M} \mathrm{NaOH}$ and a sodium silicate solution $\left(\mathrm{SiO}_{2}=29 \mathrm{wt} \%, \mathrm{Na}_{2} \mathrm{O}=10 \mathrm{wt} \%, \mathrm{H}_{2} \mathrm{O}=61 \mathrm{wt} \%\right)$. Two series of samples were prepared to investigate the effect of the activators as follows: $\mathrm{H}$-series activated with $\mathrm{NaOH}$ only, and S-series activated with the sodium silicate solution with a $\mathrm{SiO}_{2} / \mathrm{Na}_{2} \mathrm{O}$ of 1.0. The $\mathrm{Na}_{2} \mathrm{O}$ dosage of both series was $7.5 \mathrm{~g}$ per $100 \mathrm{~g}$ of fly ash. $\mathrm{The}_{2} \mathrm{O} / \mathrm{fly}$ ash was fixed at 0.338 in both series to isolate the effect of water content. Note that all the tested samples were produced from the same batch of fly ash.

Table 1. Chemical composition of fly ash obtained using XRF.

\begin{tabular}{ccccccccccc}
\hline $\mathbf{( w t} \%)$ & $\mathrm{SiO}_{2}$ & $\mathrm{Al}_{2} \mathrm{O}_{3}$ & $\mathrm{Fe}_{2} \mathrm{O}_{3}$ & $\mathrm{CaO}$ & $\mathrm{MgO}$ & $\mathrm{P}_{2} \mathrm{O}_{5}$ & $\mathrm{TiO}_{2}$ & $\mathrm{~K}_{\mathbf{2}} \mathrm{O}$ & $\mathrm{SO}_{3}$ & $\mathrm{LOI}$ \\
\hline 57.0 & 21.0 & 10.0 & 4.8 & 1.3 & 1.5 & 1.5 & 1.4 & 1.0 & 2.7 \\
\hline
\end{tabular}




\subsection{Sample Preparation}

The solids and liquids were mechanically stirred for five minutes at room temperature. The fresh samples were poured into vial molds ( $25 \mathrm{~mm}$ diameter and $50 \mathrm{~mm}$ height). The molds were placed into a chamber, and the samples were cured at $120^{\circ} \mathrm{C}$ at a pressure of $0.22 \mathrm{MPa}$ for the first $24 \mathrm{~h}$. The reference samples were cured at $120^{\circ} \mathrm{C}$ at atmospheric pressure. The samples were cured at room temperature after the first $24 \mathrm{~h}$ of curing. Note that a pressure of $0.22 \mathrm{MPa}$ was reached at this temperature, which was deemed effective in terms of the crystallization in the geopolymer $[24,26]$. The experimental parameters including mixture proportion and curing conditions employed in this study were adapted from the relevant literature $[8,16]$. This level of pressure is known to onset the crystallization of geopolymer gels $[24,26]$, and can be experienced in repository conditions.

\subsection{Experimental Methods}

The pressure-induced geopolymerization in alkali-activated fly ash was explored using synchrotron X-ray diffraction (XRD) and solid-state magic angle-spinning nuclear magnetic resonance (MAS NMR) spectroscopy at $24 \mathrm{~h}$, 7and 28 days. The samples were ground and passed through a sieve of $64 \mu \mathrm{m}$ for analysis. The synchrotron XRD was conducted at beamline $5 \mathrm{~A}$ at the Pohang Accelerator Laboratory, South Korea. The conditions for the data collection were: an angular range of $2-20^{\circ}$, a scan rate of $0.01^{\circ}$ s s and a wavelength of $0.69265 \AA$. The conditions for the solid-state ${ }^{27} \mathrm{Al}$ and ${ }^{29} \mathrm{Si}$ MAS NMR spectra collected using $600 \mathrm{MHz}$ solid-state NMR (14.1 T, unity INOVA, Agilent Technologies: Santa Clara 95050, CA, USA) at the KBSI Western Seoul Center were as follows:

- $\quad{ }^{29} \mathrm{Si}$ MAS NMR spectra: data acquisition at a transmitter frequency of $119.14 \mathrm{MHz}$, a pulse length of $30^{\circ}(2.2 \mu \mathrm{s})$, a spinning rate of $10 \mathrm{kHz}$, and a relaxation delay of $22 \mathrm{~s}$, using a $5 \mathrm{~mm}$ HX-CPMAS probe and a $5 \mathrm{~mm}$ zirconia rotor. The chemical shifts were referenced to TMS (0 ppm).

- $\quad{ }^{27}$ Al MAS NMR spectra: data acquisition at a transmitter frequency of $156.32 \mathrm{MHz}$, a pulse length of $30^{\circ}(1.8 \mu \mathrm{s})$, a spinning rate of $22 \mathrm{kHz}$, and a relaxation delay of $2 \mathrm{~s}$, using a $2.5 \mathrm{~mm}$ HX-CPMAS probe and a $2.5 \mathrm{~mm}$ low $\mathrm{Al}$ zirconia rotor. The chemical shifts were referenced to aqueous $\mathrm{AlCl}_{3}$ (0 ppm).

\section{Results}

\subsection{NaOH-Activated Samples}

The synchrotron XRD patterns of the H-series samples are shown in Figure 1. The raw fly ash showed peaks due to the presence of crystalline phases of quarts ( $\mathrm{SiO}_{2}, \mathrm{PDF} \#$ 01-089-8936), mullite $\left(\mathrm{Al}_{4.95} \mathrm{Si}_{1.05} \mathrm{O}_{9.52}\right.$, PDF\# 01-079-1450) and hematite $\left(\mathrm{Fe}_{2} \mathrm{O}_{3}\right.$, PDF\# 01-073-0603). The formation of sodalite $\left(\mathrm{Na}_{8} \mathrm{Al}_{6} \mathrm{Si}_{6} \mathrm{O}_{24}, \mathrm{PDF} \#\right.$ 01-071-5356) was observed in the XRD pattern of the H-series sample without pressure (Figure 1a). The presence of sodalite is often observed as a reaction product of $\mathrm{NaOH}$-activated fly ash and provides an analogous description of N-A-S-H in this system [27]. The presence of other zeolite minerals of zeolite A $\left(\mathrm{Na}_{12}\left(\mathrm{AlSiO}_{4}\right)_{12}, \mathrm{PDF} \#\right.$ 01-071-0370), zeolite Na-P1 ( $\mathrm{Na}_{6} \mathrm{Al}_{6} \mathrm{Si}_{10} \mathrm{O}_{32}, \mathrm{PDF}$ 01-074-1787) and Na-chabazite ( $\mathrm{Na}_{39.8} \mathrm{Al}_{70.4} \mathrm{Si}_{41.2} \mathrm{O}_{207.9}$, PDF\# 00-047-0356) was observed in the XRD pattern of the H-series sample with pressure (Figure 1b).

The ${ }^{27} \mathrm{Al}$ MAS NMR spectra of the H-series samples are shown in Figure 2a. The asymmetry in the obtained spectra was caused by the resonance of the quadrupolar nuclei, hence, the line width of the spectra was largely affected by the quadrupole moment of the nucleus, and the size of the molecule [28]. Although this technique was able to resolve the local environment of $\mathrm{Al}$ species, accurate descriptions of quadrupolar coupling effects in these materials are currently unavailable in the literature. The spectrum of the raw fly ash showed resonance centered at 52 and 1 ppm due to the presence of tetrahedral and octahedral Al sites, respectively, where the tetrahedral site corresponds to the $\mathrm{Al}$ in the tetrahedral aluminosilicate glass network [21] and the octahedral site of the mullite and mullite-like glass [14,29]. Upon alkaline activation, the spectra of the H-series samples both with and 
without pressure showed a significant reduction in the intensity of the resonance in the octahedral site, indicating the consumption of the glassy phase. The resonance at $58 \mathrm{ppm}$ was observed in these samples, which is due to the presence of tetrahedral Al in the N-A-S-H gel [21], showing a shift from $54 \mathrm{ppm}$ from the resonance of the raw fly ash. The spectrum of the sample with pressure, however, showed much narrower width at this resonance, indicating that the tetrahedral Al environment constructed herein was more clearly defined and less amorphous (i.e., crystallization). In addition, the intensity at the octahedral site was found to be lower in the sample where pressure was applied during the curing process, which implies that the reactivity was relatively higher in this sample.
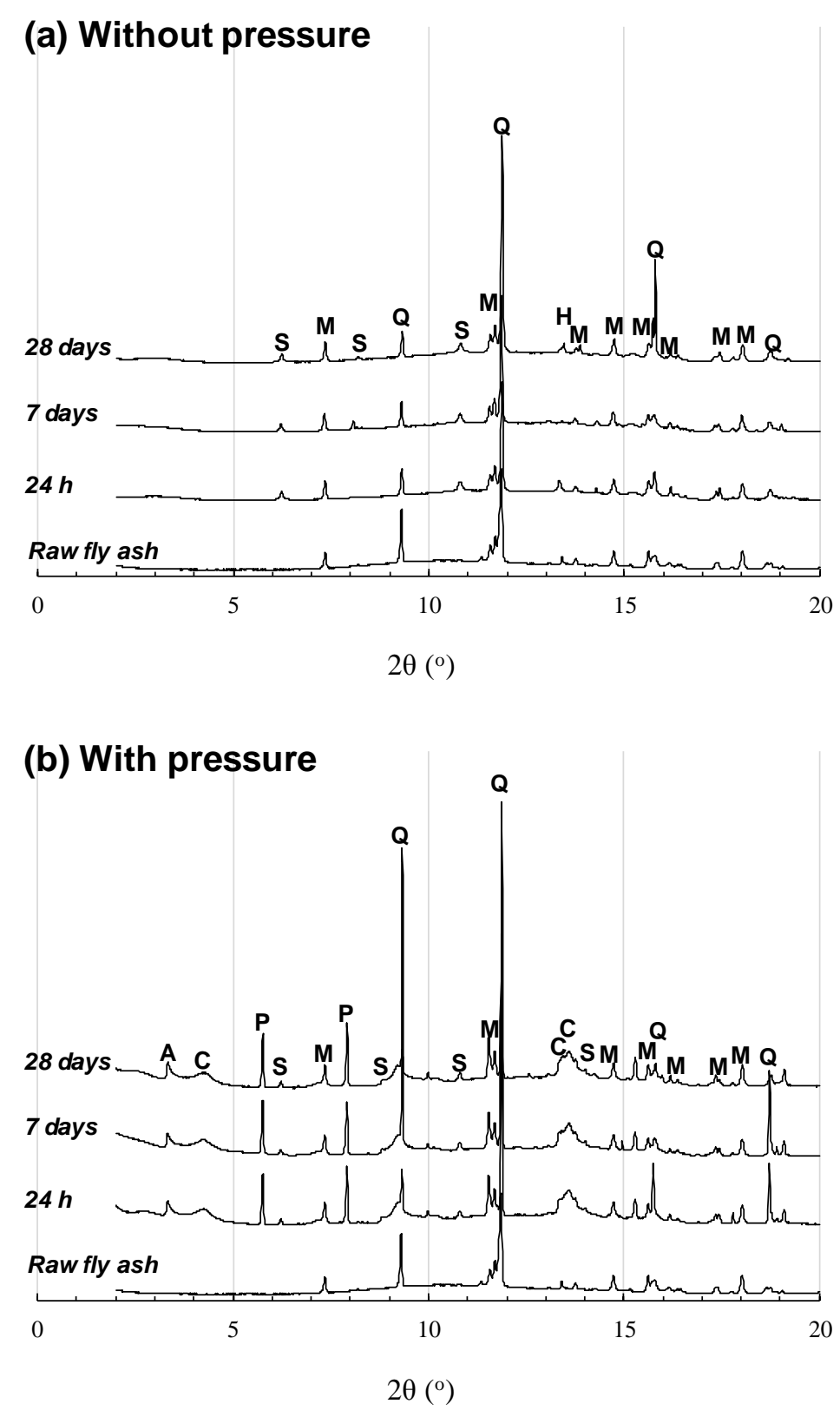

Figure 1. Synchrotron XRD patterns of $\mathrm{H}$-series samples (a) without pressure and (b) with pressure. Q-quartz, M-mullite, H-hematite, A—zeolite A, P-zeolite Na-P1, C—chabazite, and S—sodalite.

The ${ }^{29} \mathrm{Si}$ MAS NMR spectra of the H-series samples are shown in Figure $2 \mathrm{~b}$. The Si environment in both the raw and alkali-activated fly ash consists of an aluminosilicate framework, resonating at $-87,-92,-96,-103$, and $-108 \mathrm{ppm}$ due to the presence of $\mathrm{Q}^{4}(4 \mathrm{Al}), \mathrm{Q}^{4}(3 \mathrm{Al}), \mathrm{Q}^{4}(2 \mathrm{Al}), \mathrm{Q}^{4}(1 \mathrm{Al})$, and $\mathrm{Q}^{4}(0 \mathrm{Al})$, respectively $[21,30,31]$. The resonance of $\mathrm{Q}^{4}(0 \mathrm{Al})$ due to the Si-O-Si linkage in the 
crystalline (i.e., quartz) or glassy phase [32,33] was relatively lower in the sample with pressure. This implies that the reactivity of the fly ash vastly improved in elevated pressure conditions. The sample without pressure mostly displayed the highest intensity at the $\mathrm{Q}^{4}(4 \mathrm{Al})$ site and an increased resonance at the $\mathrm{Q}^{4}(3 \mathrm{Al})$ site at 28 days. In contrast, the sample with pressure showed the highest intensity at the $\mathrm{Q}^{4}(2 \mathrm{Al})$ and $\mathrm{Q}^{4}(1 \mathrm{Al})$ sites throughout all ages, implying that the elevated pressure was effective for the formation of Si-rich reaction products even at an early age. The resonance at these two sites was much narrower due to the higher degree of crystallization in the sample with pressure.

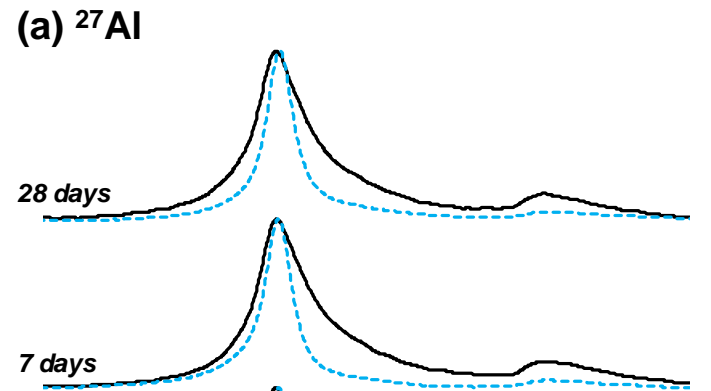

$$
\text { (b) }{ }^{29} \mathrm{Si}
$$

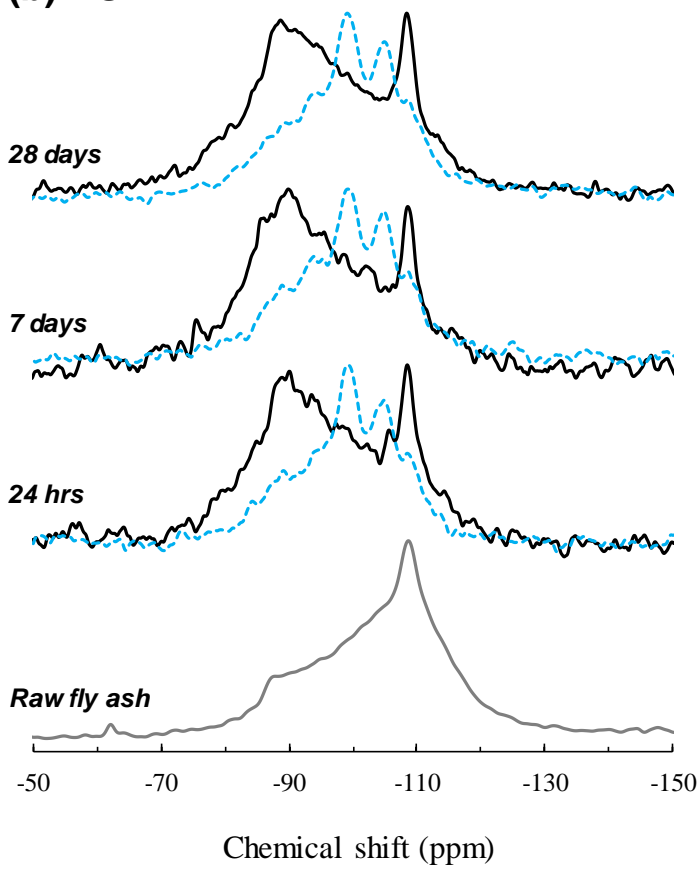

(b) ${ }^{29} \mathrm{Si}$
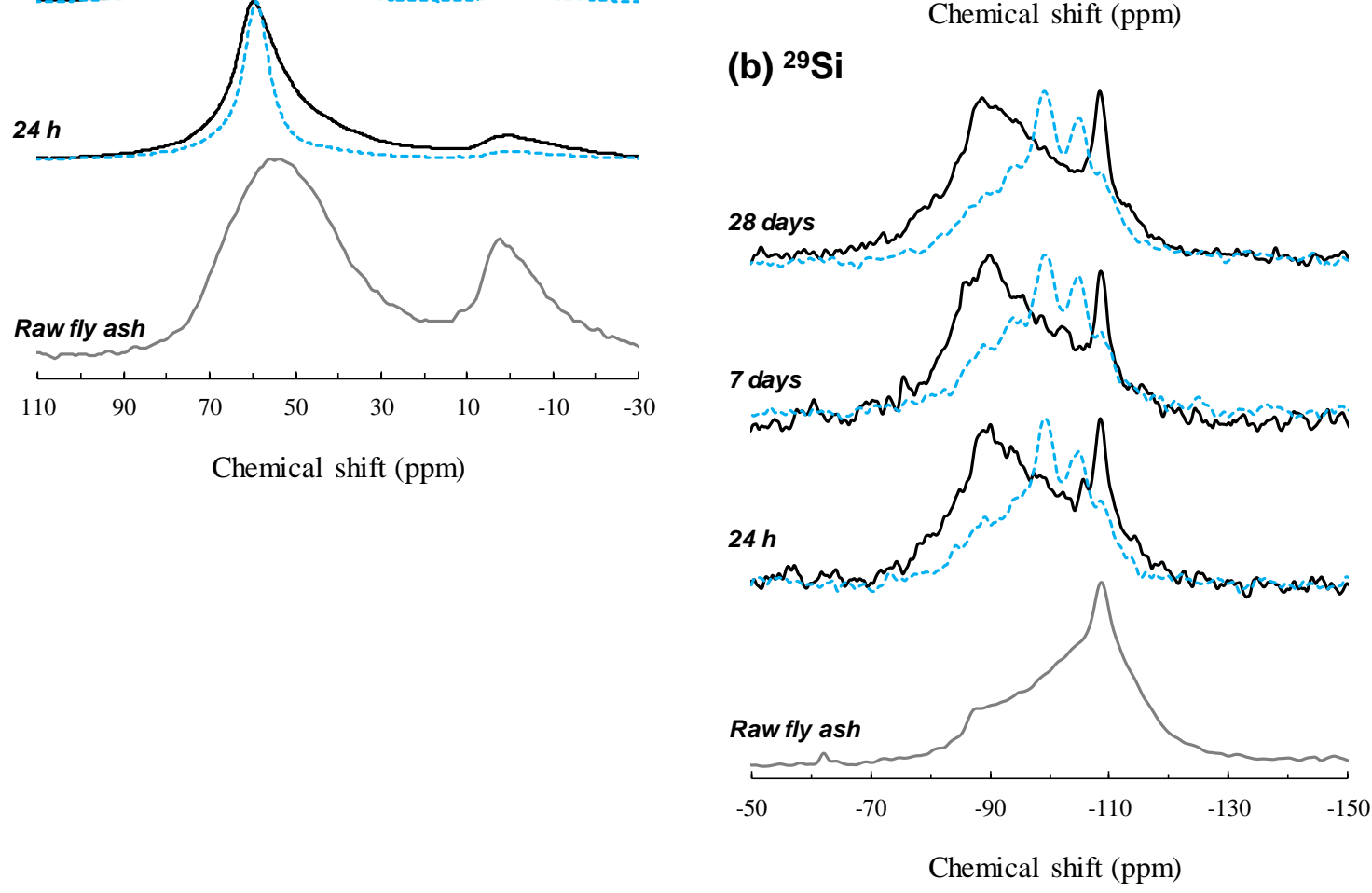

Figure 2. (a) ${ }^{27} \mathrm{Al}$ and (b) ${ }^{29} \mathrm{Si} \mathrm{MAS} \mathrm{NMR} \mathrm{spectra} \mathrm{of} \mathrm{H-series} \mathrm{samples.} \mathrm{The} \mathrm{black} \mathrm{solid} \mathrm{and} \mathrm{blue} \mathrm{dotted}$ lines indicate the spectra of the reference sample and the sample with pressure, respectively. 


\subsection{Sodium Silicate-Series Samples}

The synchrotron XRD patterns of the S-series samples are shown in Figure 3. The XRD patterns of the samples with and without pressure showed the peaks corresponding to the presence of crystalline phases contained in the raw fly ash, i.e., quartz, mullite and hematite. The absence of peaks attributed to zeolite minerals indicates that the growth of zeolite crystals (or zeolite with a sufficient degree of crystallinity) was significantly hindered by the dissolved silica, even with the elevated pressure. The effect of pressure on the reactivity of the fly ash was seen to be much less in comparison with the H-series; the intensity of the octahedral site in the ${ }^{27} \mathrm{Al}$ MAS NMR spectrum of the sample with pressure was only slightly reduced (Figure $4 \mathrm{a}$ ); and the resonance at the $\mathrm{Q}^{4}(0 \mathrm{Al})$ in the ${ }^{29} \mathrm{Si}$ MAS NMR spectra was similar to that of the sample without pressure.

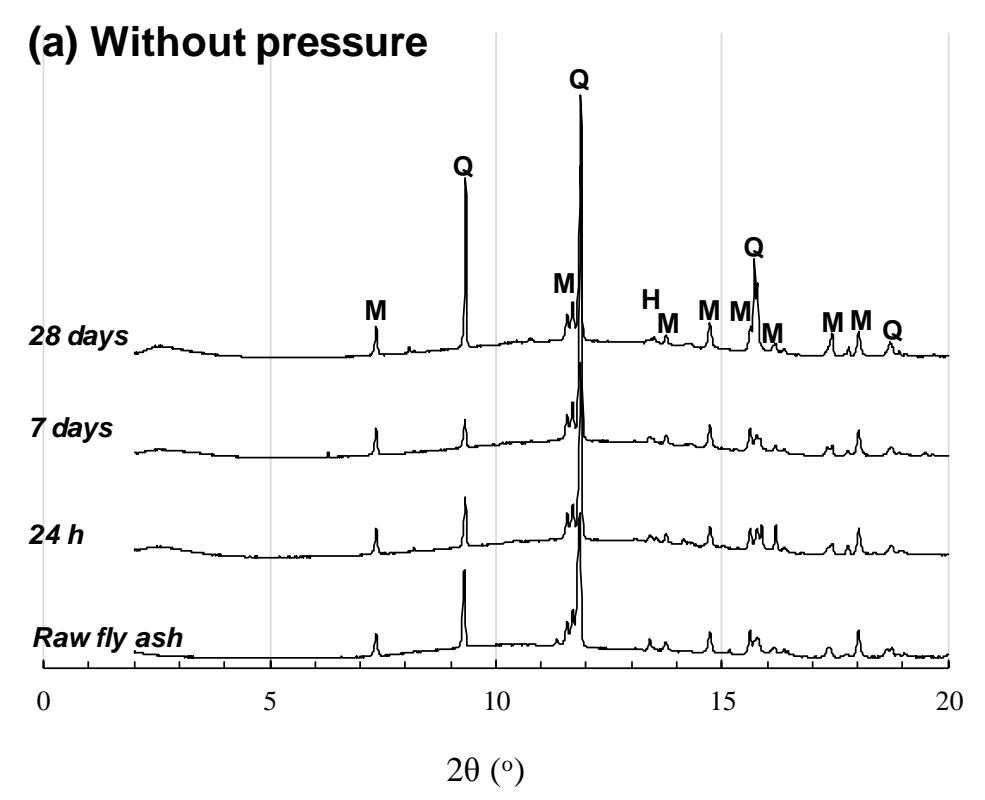

\section{(b) With pressure}

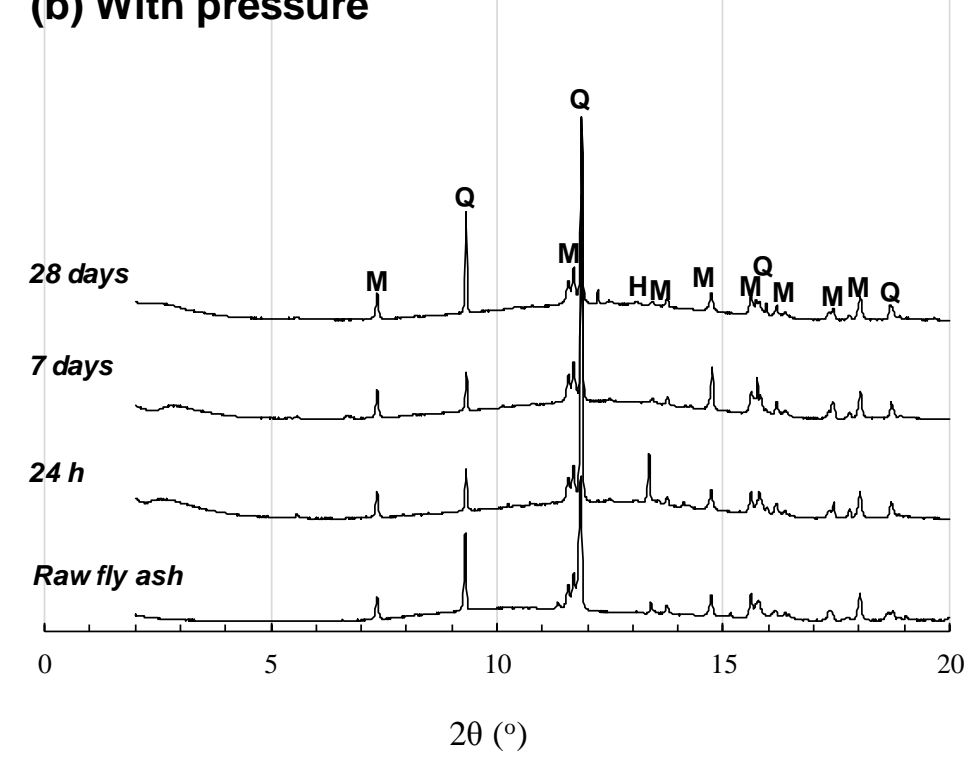

Figure 3. Synchrotron XRD patterns of $S$-series samples (a) without pressure and (b) with pressure. Q-quartz, M-mullite, H-hematite, A—zeolite A, P-zeolite P, C—chabazite, and S—sodalite. 
(a) ${ }^{27} \mathrm{Al}$
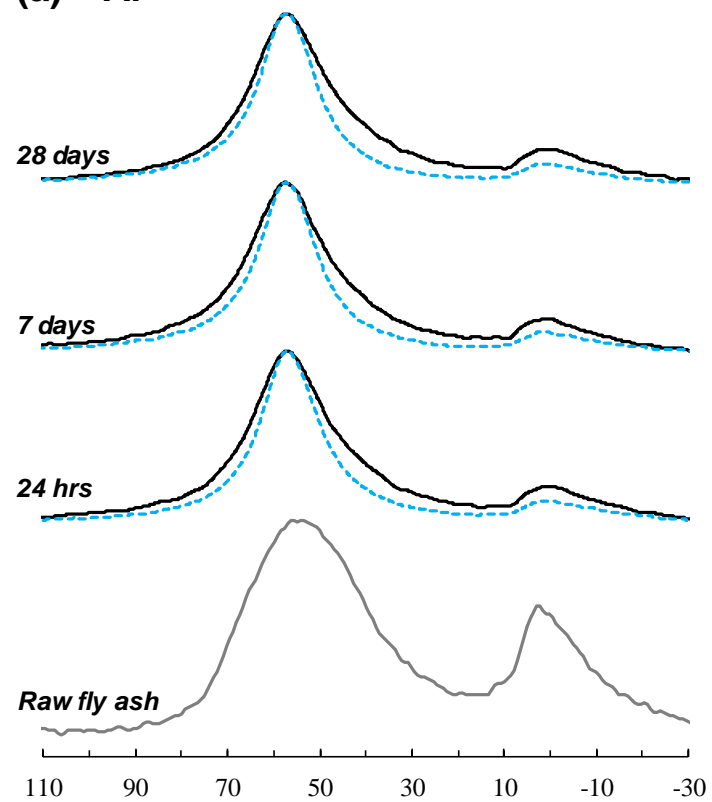

Chemical shift (ppm)

(a) ${ }^{27} \mathrm{Al}$
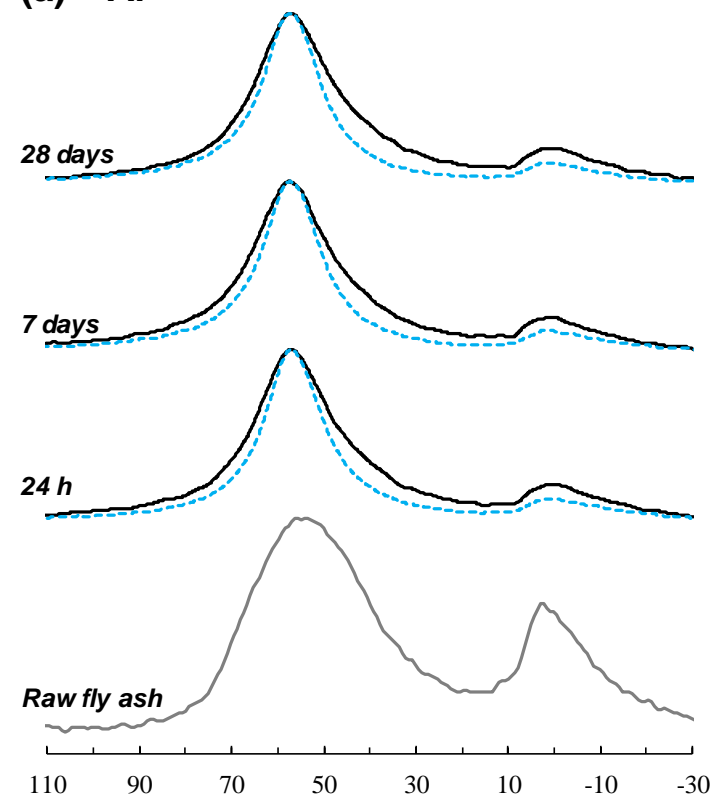

Chemical shift (ppm) (b) ${ }^{29} \mathrm{Si}$

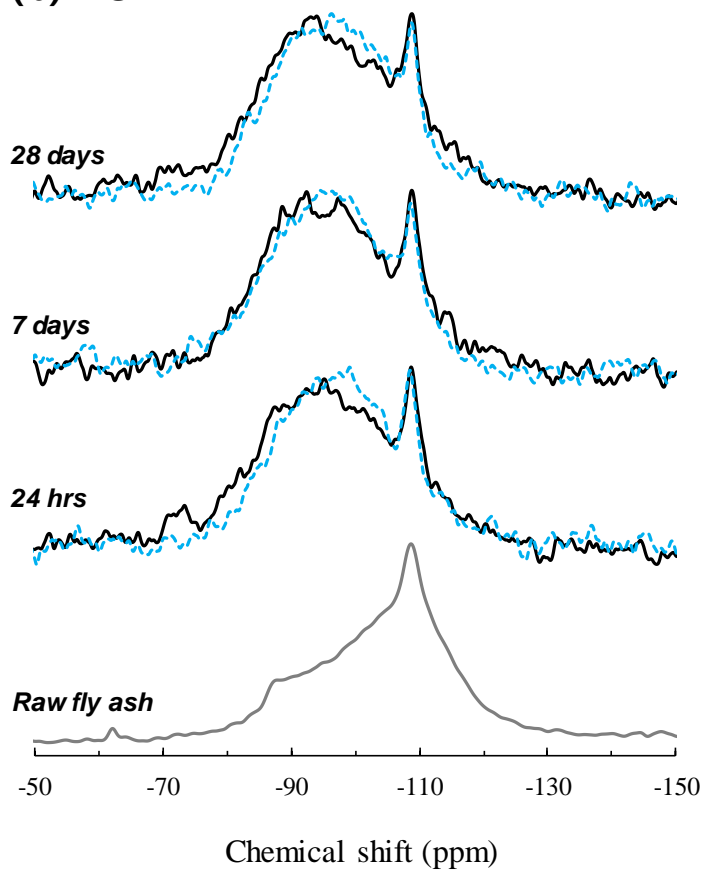

(b) ${ }^{29} \mathrm{Si}$

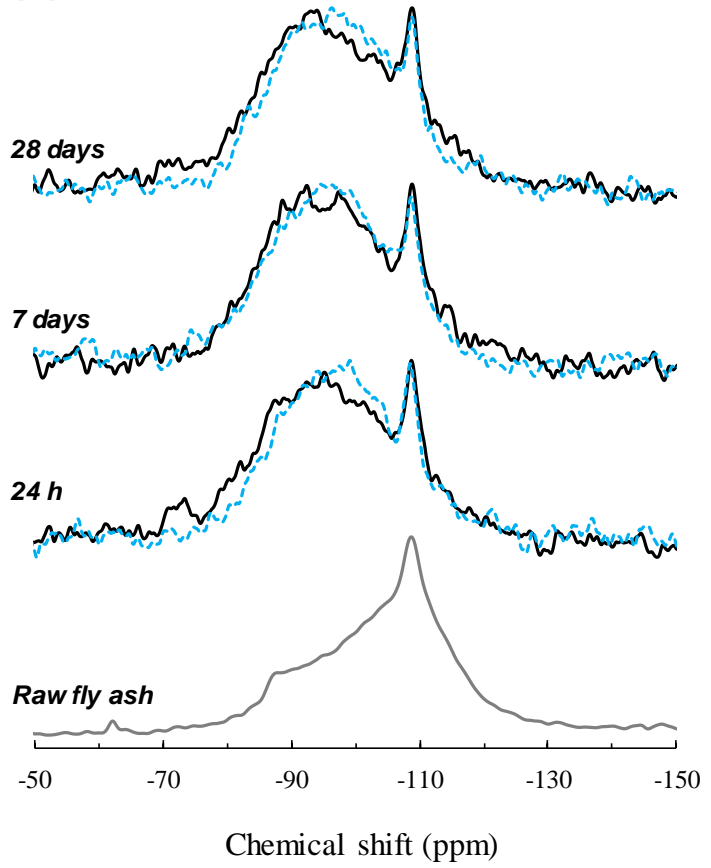

Figure 4. (a) ${ }^{27} \mathrm{Al}$ and (b) ${ }^{29} \mathrm{Si} \mathrm{MAS} \mathrm{NMR} \mathrm{spectra} \mathrm{of} \mathrm{S-series} \mathrm{samples.} \mathrm{The} \mathrm{black} \mathrm{solid} \mathrm{and} \mathrm{blue} \mathrm{dotted}$ lines indicate the spectra of the reference sample and the sample with pressure, respectively.

\section{Discussion}

Previous studies reported that $\mathrm{NaOH}$-activated metakaolin and slag generally show a higher tendency of crystallization over time in comparison with those activated with sodium silicate $[34,35]$. A similar result was observed in this study, in which the H-series samples exhibited a higher extent of crystallization in elevated pressure conditions. An ageing phenomenon of geopolymers is generally accepted to accompany crystallization [36] in a similar manner to that of hydrated calcium aluminate cement, in which hydrates (mainly calcium aluminate octa- and deca-hydrate) lose structural water, increasing the pore volume [37]. The difference between the ageing phenomena of the two binder 
systems is the presence of water; neither geopolymer gels nor zeolite crystals contain as much water as calcium aluminate cement hydrates, hence the ageing effect of geopolymers is not associated with the release of structural water from the binder gel, but instead is related to the density of the tetrahedral per unit volume which is significantly reduced by crystallization from amorphous gel into zeolite [36]. Such phenomena were validated in the case of the alkali-activated metakaolin, which experienced a significant loss in compressive strength after 28 days of ageing at $95^{\circ} \mathrm{C}$ [36]. Moreover, the strength loss was approximately in an inverse relationship with the content of zeolite P [36].

To date, only a few studies have looked at the ageing effect of alkali-activated fly ash (i.e., [36,38]). For instance, fly ash activated with sodium silicate solutions with varying compositions $\left(7 \% \mathrm{SiO}_{2}\right.$ and $7-15 \% \mathrm{Na}_{2} \mathrm{O}$ by the mass of fly ash) showed a higher content of faujasite in a system with lower $\mathrm{Na}_{2} \mathrm{O}$, and a higher content of zeolite $\mathrm{P}$ in a system with higher $\mathrm{Na}_{2} \mathrm{O}$ [36]. Considering that zeolite $\mathrm{A}$ [39] and faujasite [40] succeed to zeolite $\mathrm{P}$, the presence of these zeolite crystals in the H-series sample with elevated pressure may correlate to its likely durability performance. Specifically, employing $\mathrm{NaOH}$ as an activator for fly ash could be plausible for use as a structural element where long-term durability is mandatory, and where mechanical properties are of less concern (i.e., molecular sieve [41] or radioactive waste immobilization $[24,26])$. On the other hand, the zeolite phases formed in these samples may not be considered to have followed a general phenomenon, since the synthesis of zeolites is significantly influenced by temperature [42]. In particular, the formation of zeolite Na-P1 or sodalite is reportedly preferred at the temperature applied in this study $\left(120^{\circ} \mathrm{C}\right)$ [43].

\section{Conclusions}

The present study explored pressure-induced geopolymerization in alkali-activated fly ash using synchrotron XRD and solid-state MAS NMR spectroscopy. Two series of samples were prepared, one activated with $\mathrm{NaOH}$ (H-series) and another one activated with a sodium silicate solution (S-series). An elevated pressure was applied during the initial curing stage at an elevated temperature for $24 \mathrm{~h}$. The synchrotron XRD results showed that significant growth of zeolites (zeolite A, zeolite Na-P1, chabazite, sodalite) in the H-series samples was induced by pressure, while the S-series samples remained amorphous in identical conditions. The NMR spectra of the samples suggest that the reactivity of the fly ash, or geopolymerization in the $\mathrm{H}$-series samples was enhanced by pressure to a greater extent than that of the S-series samples.

The obtained results showed that the elevated pressure was effective in enhancing the reactivity of the fly ash and growth of the zeolite crystals in the H-series samples. The geopolymer gel in the sample with pressure was relatively rich in $\mathrm{Si}$. In contrast, the effects of elevated pressure were much less clear in the S-series samples, showing that the dissolved silica that was supplied by the activator inhibited the crystallization of the binder gel. The crystallization of the binder gel can be viewed in two different aspects. First, the ageing of geopolymer gels tends to induce microstructural changes that may affect their mechanical properties [44], while zeolite formation plays an important role as an ion adsorbent $[24,26]$.

Further research is necessary to reveal the crystallization of fly ash-based geopolymers and their mechanical properties. The crystallization of this binder system was found to be less likely in comparison with that of metakaolin. The results obtained in this study suggest that alkali-activated fly ash can undergo significant crystallization when activated with $\mathrm{NaOH}$ under elevated pressure. In addition, the phase transformation of zeolite formed in this binder system may be an important topic of future studies, since it is highly related to the ion sorption kinetics and capacity. The influence of zeolite crystallization on the mechanical properties of these materials could be an important factor, which should be explored in forthcoming studies.

Author Contributions: Conceptualization S.M.P. and H.R.K.; methodology and experimentation S.M.P., J.H.S., H.N.Y., S.H.K. and H.M.S.; data analysis, S.M.P., N.K.L., H.K.L. and J.G.J.; supervision, N.K.L., H.K.L. and J.G.J.; writing-original draft preparation, S.M.P. and H.R.K.; project administration, H.K.L.; and funding acquisition, H.K.L. 
Funding: This study was supported by the National Research Foundation (NRF) of the Korean government (Ministry of Science \& ICT) [Grant Number: 2017R1A5A1014883] through the Smart Submerged Floating Tunnel System Research Center.

Acknowledgments: The authors acknowledge the use of the solid-state NMR spectrometer at Korea Basic Science Institute Western Seoul center. Experiments using X-ray synchrotron radiation at beamline 5A (PLS-II) were supported by the Ministry of Science \& ICT and POSTECH in Korea.

Conflicts of Interest: The authors declare no conflicts of interest.

\section{References}

1. Provis, J.L. Alkali-activated materials. Cem. Concr. Res. 2017, in press. [CrossRef]

2. Provis, J.L.; Palomo, A.; Shi, C. Advances in understanding alkali-activated materials. Cem. Concr. Res. 2015, 78, 110-125. [CrossRef]

3. McLellan, B.C.; Williams, R.P.; Lay, J.; van Riessen, A.; Corder, G.D. Costs and carbon emissions for geopolymer pastes in comparison to ordinary portland cement. J. Clean. Prod. 2011, 19, 1080-1090. [CrossRef]

4. Duxson, P.; Fernández-Jiménez, A.; Provis, J.L.; Lukey, G.C.; Palomo, A.; van Deventer, J. Geopolymer technology: The current state of the art. J. Mater. Sci. 2007, 42, 2917-2933. [CrossRef]

5. Duxson, P.; Provis, J.L.; Lukey, G.C.; van Deventer, J.S. The role of inorganic polymer technology in the development of 'green concrete'. Cem. Concr. Res. 2007, 37, 1590-1597. [CrossRef]

6. Bernal, S.A.; Provis, J.L. Durability of Alkali-Activated Materials: Progress and Perspectives. J. Am. Ceram. Soc. 2014, 97, 997-1008. [CrossRef]

7. Provis, J.L. Geopolymers and other alkali activated materials: Why, how, and what? Mater. Struct. 2014, 47, 11-25. [CrossRef]

8. Jang, J.; Park, S.; Lee, H. Physical barrier effect of geopolymeric waste form on diffusivity of cesium and strontium. J. Hazard. Mater. 2016, 318, 339-346. [CrossRef] [PubMed]

9. Kriven, W.M. Geopolymer-Based Composites. In Comprehensive Composite Materials II; Beaumont, P.W.R., Zweben, C.H., Eds.; Elsevier: Oxford, UK, 2018; pp. 269-280.

10. Moon, J.; Bae, S.; Celik, K.; Yoon, S.; Kim, K.-H.; Kim, K.S.; Monteiro, P.J. Characterization of natural pozzolan-based geopolymeric binders. Cem. Concr. Compos. 2014, 53, 97-104. [CrossRef]

11. Singh, G.B.; Subramaniam, K.V. Evaluation of sodium content and sodium hydroxide molarity on compressive strength of alkali activated low-calcium fly ash. Cem. Concr. Compos. 2017, 81, 122-132. [CrossRef]

12. Walkley, B.; Rees, G.J.; Nicolas, R.S.; van Deventer, J.S.; Hanna, J.V.; Provis, J.L. New Structural Model of Hydrous Sodium Aluminosilicate Gels and the Role of Charge-Balancing Extra-Framework Al. J. Phys. Chem. C 2018, 122, 5673-5685. [CrossRef]

13. Jang, J.; Park, S.; Kim, G.; Lee, H.-K. Stability of MgO-modified geopolymeric gel structure exposed to a $\mathrm{CO}_{2}$-rich environment. Constr. Build. Mater. 2017, 151, 178-185. [CrossRef]

14. Park, S.-M.; Jang, J.-G.; Chae, S.; Lee, H.-K. An NMR Spectroscopic Investigation of Aluminosilicate Gel in Alkali-Activated Fly Ash in a $\mathrm{CO}_{2}$-Rich Environment. Materials 2016, 9, 308. [CrossRef] [PubMed]

15. Lee, N.; Lee, H. Influence of the slag content on the chloride and sulfuric acid resistances of alkali-activated fly ash/slag paste. Cem. Concr. Compos. 2016, 72, 168-179. [CrossRef]

16. Khalid, H.R.; Lee, N.; Park, S.; Abbas, N.; Lee, H. Synthesis of geopolymer-supported zeolites via robust one-step method and their adsorption potential. J. Hazard. Mater. 2018, 353, 522-533. [CrossRef] [PubMed]

17. Al-Zboon, K.; Al-Harahsheh, M.S.; Hani, F.B. Fly ash-based geopolymer for Pb removal from aqueous solution. J. Hazard. Mater. 2011, 188, 414-421. [CrossRef] [PubMed]

18. Jang, J.G.; Park, S.M.; Lee, H.K. Cesium and Strontium Retentions Governed by Aluminosilicate Gel in Alkali-Activated Cements. Materials 2017, 10, 447. [CrossRef] [PubMed]

19. Li, Q.; Sun, Z.; Tao, D.; Xu, Y.; Li, P.; Cui, H.; Zhai, J. Immobilization of simulated radionuclide $133 \mathrm{Cs}^{+}$by fly ash-based geopolymer. J. Hazard. Mater. 2013, 262, 325-331. [CrossRef] [PubMed]

20. De Silva, P.; Sagoe-Crenstil, K. Medium-term phase stability of $\mathrm{Na}_{2} \mathrm{O}-\mathrm{Al}_{2} \mathrm{O}_{3}-\mathrm{SiO}_{2}-\mathrm{H}_{2} \mathrm{O}$ geopolymer systems. Cem. Concr. Res. 2008, 38, 870-876. [CrossRef]

21. Palomo, A.; Alonso, S.; Fernandez-Jiménez, A.; Sobrados, I.; Sanz, J. Alkaline activation of fly ashes: NMR study of the reaction products. J. Am. Ceram. Soc. 2004, 87, 1141-1145. [CrossRef] 
22. Fernández-Jiménez, A.; Palomo, A. Characterisation of fly ashes. Potential reactivity as alkaline cements. Fuel 2003, 82, 2259-2265. [CrossRef]

23. Jang, J.G.; Lee, H.-K. Effect of fly ash characteristics on delayed high-strength development of geopolymers. Constr. Build. Mater. 2016, 102, 260-269. [CrossRef]

24. Lee, N.; Khalid, H.R.; Lee, H. Synthesis of mesoporous geopolymers containing zeolite phases by a hydrothermal treatment. Microporous Mesoporous Mater. 2016, 229, 22-30. [CrossRef]

25. Xu, R.; Pang, W.; Yu, J.; Huo, Q.; Chen, J. Chemistry of Zeolites and Related Porous Materials: Synthesis and Structure; John Wiley \& Sons: New York, NY, USA, 2009.

26. Lee, N.; Khalid, H.R.; Lee, H. Adsorption characteristics of cesium onto mesoporous geopolymers containing nano-crystalline zeolites. Microporous Mesoporous Mater. 2017, 242, 238-244. [CrossRef]

27. Oh, J.E.; Moon, J.; Mancio, M.; Clark, S.M.; Monteiro, P.J. Bulk modulus of basic sodalite, $\mathrm{Na}_{8}\left[\mathrm{AlSiO}_{4}\right]_{6}(\mathrm{OH})_{2} \cdot 2 \mathrm{H}_{2} \mathrm{O}$, a possible zeolitic precursor in coal-fly-ash-based geopolymers. Cem. Concr. Res. 2011, 41, 107-112. [CrossRef]

28. De Lacaillerie, J.-B.d.E.; Fretigny, C.; Massiot, D. MAS NMR spectra of quadrupolar nuclei in disordered solids: The Czjzek model. J. Magn. Reson. 2008, 192, 244-251. [CrossRef] [PubMed]

29. Merwin, L.; Sebald, A.; Rager, H.; Schneider, H. ${ }^{29} \mathrm{Si}$ and ${ }^{27} \mathrm{Al}$ MAS NMR spectroscopy of mullite. Phys. Chem. Miner. 1991, 18, 47-52. [CrossRef]

30. Madani, A.; Aznar, A.; Sanz, J.; Serratosa, J. Silicon-29 and aluminum-27 NMR study of zeolite formation from alkali-leached kaolinites: Influence of thermal preactivation. J. Phys. Chem. 1990, 94, 760-765. [CrossRef]

31. Park, S.; Jang, J.; Lee, N.; Lee, H. Physicochemical properties of binder gel in alkali-activated fly ash/slag exposed to high temperatures. Cem. Concr. Res. 2016, 89, 72-79. [CrossRef]

32. Bernal, S.A.; Provis, J.L.; Walkley, B.; Nicolas, R.S.; Gehman, J.D.; Brice, D.G.; Kilcullen, A.R.; Duxson, P.; van Deventer, J.S. Gel nanostructure in alkali-activated binders based on slag and fly ash, and effects of accelerated carbonation. Cem. Concr. Res. 2013, 53, 127-144. [CrossRef]

33. Kowalczyk, G.; Roberts, J.E. Solid state ${ }^{29} \mathrm{Si}$ NMR determination of crystalline silica in natural iron oxide pigments. Anal. Chim. Acta 1994, 286, 25-35. [CrossRef]

34. White, C.E.; Provis, J.L.; Bloomer, B.; Henson, N.J.; Page, K. In situ X-ray pair distribution function analysis of geopolymer gel nanostructure formation kinetics. Phys. Chem. Chem. Phys. 2013, 15, 8573-8582. [CrossRef] [PubMed]

35. White, C.E.; Provis, J.L.; Llobet, A.; Proffen, T.; van Deventer, J.S. Evolution of local structure in geopolymer gels: An in situ neutron pair distribution function analysis. J. Am. Ceram. Soc. 2011, 94, 3532-3539. [CrossRef]

36. Lloyd, R. Accelerated ageing of geopolymers. In Geopolymers: Structure, Processing, Properties and Industrial Applications; Woodhead Publishing: Sawston, UK, 2009; pp. 139-166.

37. Rashid, S.; Barnes, P.; Bensted, J.; Turrillas, X. Conversion of calcium aluminate cement hydrates re-examined with synchrotron energy-dispersive diffraction. J. Mater. Sci. Lett. 1994, 13, 1232-1234. [CrossRef]

38. Rees, C.A.; Provis, J.L.; Lukey, G.C.; van Deventer, J.S. Attenuated total reflectance fourier transform infrared analysis of fly ash geopolymer gel aging. Langmuir 2007, 23, 8170-8179. [CrossRef] [PubMed]

39. Rees, L.V.; Chandrasekhar, S. Formation of zeolite from the system $\mathrm{Na}_{2} \mathrm{O}-\mathrm{Al}_{2} \mathrm{O}_{3}-\mathrm{SiO}_{2}-\mathrm{H}_{2} \mathrm{O}$ in alkaline medium ( $\mathrm{pH}>10)$. Zeolites 1993, 13, 524-533. [CrossRef]

40. Katović, A.; Subotić, B.; Šmit, I.; Despotović, L.A. Crystallization of tetragonal $\left(B_{8}\right)$ and cubic $\left(B_{1}\right)$ modifications of zeolite NaP from freshly prepared gel. Part 1. Mechanism of the crystallization. Zeolites 1989, 9, 45-53. [CrossRef]

41. Provis, J.L.; Lukey, G.C.; van Deventer, J.S. Do geopolymers actually contain nanocrystalline zeolites? A reexamination of existing results. Chem. Mater. 2005, 17, 3075-3085. [CrossRef]

42. Kotova, O.; Shabalin, I.; Shushkov, D.; Kocheva, L. Hydrothermal synthesis of zeolites from coal fly ash. Adv. Appl. Ceram. 2016, 115, 152-157. [CrossRef] 
43. Król, M.; Morawska, J.; Mozgawa, W.; Pichór, W. Low-temperature synthesis of zeolite from perlite waste-Part I: Review of methods and phase compositions of resulting products. Mater. Sci.-Pol. 2014, 32, 503-513. [CrossRef]

44. Duxson, P.; Mallicoat, S.; Lukey, G.; Kriven, W.; van Deventer, J. The effect of alkali and Si/Al ratio on the development of mechanical properties of metakaolin-based geopolymers. Colloids Surf. A Physicochem. Eng. Asp. 2007, 292, 8-20. [CrossRef]

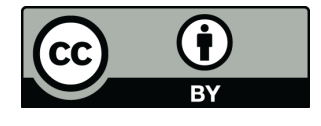

(C) 2018 by the authors. Licensee MDPI, Basel, Switzerland. This article is an open access article distributed under the terms and conditions of the Creative Commons Attribution (CC BY) license (http:/ / creativecommons.org/licenses/by/4.0/). 